\title{
Chemistry for whom? Gender awareness in teaching and learning chemistry
}

\author{
Kristina Andersson ${ }^{1}$
}

Received: 17 May 2016/Accepted: 4 October 2016/Published online: 19 November 2016

(C) The Author(s) 2016. This article is published with open access at Springerlink.com

\begin{abstract}
Marie Ståhl and Anita Hussénius have defined what discourses dominate national tests in chemistry for Grade 9 in Sweden by using feminist, critical didactic perspectives. This response seeks to expand the results in Ståhl and Hussénius's article Chemistry inside an epistemological community box!-Discursive exclusions and inclusions in the Swedish national tests in chemistry, by using different facets of gender awareness. The first facet-Gender awareness in relations to the test designers' own conceptions-highlighted how the gender order where women are subordinated men becomes visible in the national tests as a consequence of the test designers internalized conceptions. The second facet-Gender awareness in relation to chemistry-discussed the hierarchy between discourses within chemistry. The third facet-Gender awareness in relation to students-problematized chemistry in relation to the students' identity formation. In summary, I suggest that the different discourses can open up new ways to interpret chemistry and perhaps dismantle the hegemonic chemistry discourse.
\end{abstract}

Keywords Chemistry · Gender awareness · Hegemonic chemistry discourse · Identity · Sustainable development

A number of years ago I was invited to an upper secondary school in the middle of Sweden to give a talk about gender perspectives in science teaching. The lecture was divided into

Lead Editor: K. Scantlebury.

This forum addresses issues raised in Marie Ståhl and Anita Hussénius's paper entitled: Chemistry inside an epistemological community box!-Discursive exclusions and inclusions in the Swedish national tests in chemistry.. doi:10.1007/s11422-016-9730-z.

Kristina Andersson

kristina.andersson@gender.uu.se

1 Uppsala University, Uppsala, Sweden 
two parts: I began by discussing feminist theories in science based on scholars such as Sandra Harding (1986) and Evelyn Fox Keller and Helen Longino (1996), and in the second part, I described the consequences that the gender hierarchy and our notions about gender have on teaching and learning science. Here I presented some of the findings in Britt Lindahl's dissertation (2003), where she shows that girls who perform well in science subjects in Grade 9 opted out of science programs in upper secondary school. One of the reasons the girls gave for their waning interest during secondary school was that the teaching of science was marked by understanding and defining concepts, where often there was one right answer. They compared these with social sciences, where there is room for discussion, argument, and establishing one's own position, which appealed to them to a much higher degree.

After the talk, an upper secondary school teacher approached me to discuss some of Lindahl's results. She said,

How interesting it is to hear about girls who preferred the social sciences because you could discuss and argue. For me it was just the opposite; I preferred the natural sciences because there was no discussion! There was a precision, so you could get an answer to your questions and find out how it really was. That's what attracted me. (My field notes, 28th of February 2006)

After having read Marie Ståhl and Anita Hussénius's study, Chemistry inside an epistemological community box!-Discursive exclusions and inclusions in the Swedish national tests in chemistry, I wanted to continue the discussion of to whom science teaching is directed, particularly in relation to chemistry subject content. What can a feminist perspective bring, and what do the different facets of gender awareness mean for teachers, test designers, textbook authors and researchers?

\section{Background}

International studies such as PISA and TIMSS that investigate students' knowledge in various subjects are gaining influence in countries' political decisions about educational systems (Jakobsson 2013). In Sweden, the government introduced compulsory national tests in 2009/2010 in natural science subjects, biology, chemistry or physics, for Grade 9 students, which are argued to ensure a fair assessment and grading of students. It has been shown that these tests will act as a performance measure and thereby will guide teachers in what is considered important to teach (Lundqvist and Lidar 2013). Because the tests, internationally as well as nationally, will be important for teaching approach to the natural sciences, it is important that research in science education analyzes different aspects of the tests and the test questions. In their article, Ståhl and Hussénius have examined the standards and values embedded within national tests in chemistry by means of discourse analysis with a feminist, critical didactic perspective. By analyzing 100 test questions from a total of four different tests, they define the two main discourses: The Disciplinary and Transgressive Discourse Group, which also have commonalities with Douglas Roberts' Vision I and Vision II (2007). The Disciplinary Discourse Group consists of three subdiscourses (The Naked Discourse, The Backdrop Discourse and the Border Discourse), all of which mainly deal with factual knowledge, where the questions usually have only one correct answer. Within the Transgressive Discourse Group (Ståhl and Hussénius group the Sustainable Development Discourse, the Everyday Discourse, the Historical Discourse and 
the Chemistry Influence Discourse under this theme), there is a commendable ambition to broaden the test beyond simply a recollection of facts to also include other aspects, such as practice in making arguments, everyday chemistry content, discussions about environmental consequences and other tasks, and therefore, a portion of the questions are also open in their design. However, these are parts that should be included in the teaching of chemistry in Swedish primary schools. The chemistry curriculum says the following:

The teaching should give students opportunities to use and develop knowledge and tools to formulate their own and review others' arguments in contexts where knowledge in chemistry has meaning. Thus, students should be given opportunities to manage practical ethical and aesthetic choices in situations related to energy, the environment, health and society. The teaching should help students develop a familiarity with chemistry concepts, models and theories as well as an understanding of how these are formed in conjunction with experiences from investigations of the world around them. Furthermore, the teaching should contribute to students' developing abilities to discuss, interpret and produce texts and different aesthetic expressions for scientific content. (Swedish National Agency for Education 2011, Chemistry Curriculum, Subject Goals)

However, what emerges in Ståhl and Hussénius's results is that in matters where students are to argue with help of scientific texts, the "scientific knowledge" is narrowly defined. In the answer possibilities that are given as correct in the guidelines for the national tests, there is no space for students to make social, economic or aesthetic arguments linked to science. In the questions that are grouped in the discourse "Chemistry Influence Discourse," chemistry is predominantly valued as an area that has led to welfare and progress, whereas the negative effects on the environment and on equity in the world are toned down.

\section{Three facets of gender awareness as tools for the interpretation of teaching and learning in chemistry}

In one of the studies in my dissertation, using action research methodology, I examined teachers', including preschool teachers', gender awareness in relation to science activities (Andersson 2011). The study showed that gender work is complicated because it involves many aspects of life, and an important part of gender awareness is relating oneself to these different aspects. It is essential to challenge notions of gender as the challenges will result in these notions becoming verbalized and thus possible to change. The study also showed that by taking its starting point in feminist science criticism and pedagogy, an alternative way of relating to the teaching and learning of science can become possible (Andersson and Gullberg 2014). One conclusion is that knowledge of gender can be seen as part of a teacher's pedagogical content knowledge and that this gender knowledge can be described as an awareness seen through three different facets. First, gender awareness in relation to teachers' own beliefs, where teachers examine themselves and their views about notions of sex/gender as well as science. Second, gender awareness in relation to the natural sciences (in this article, chemistry) that become problematized and reviewed, and third, gender awareness in relation to the students to effect change/improvements within science teaching and learning (Andersson 2011). These three facets provide a framework for my continued discussion of the results in Ståhl and Hussénius's article. They are here used as 
an analytical tool to get sight of how gender interplay in the different discourses described in their study. The facets can also be used as a tool for teachers when they are planning and evaluating their teaching and, moreover, in most cases the test designers are teachers or former teachers.

\section{Facet 1: gender awareness in relations to the test designers' own conceptions}

Sweden comes in fourth place for gender equity in the 2015 Gender Gap Index (The Global Gender Gap Report 2015), which could be interpreted to mean that gender equality is a goal that has been implemented at various levels of society and that all citizens are well aware of. But awareness of the importance of an equitable society does not mean that gender stereotypes or even prejudices are out of Swedish citizens' thought structures.

Ståhl and Hussenius's use of a feminist theoretical framework made it possible to dissect test questions and uncover hidden norms and values. Through their analysis, they showed that the tests also reproduce ideas about women/girls as intellectually subordinate to men/boys through images and text passages that present women/girls who are the ignorant in terms of chemistry knowledge. In later tests, these prejudices against women are not as explicit, but the representations have a gender bias in the form of presenting scientists, entrepreneurs and other positive models as men. One might think that the test engineers that created the choice of illustrations, the representations of gender, ethnicity, etc. in the questions would be very careful to show diversity, but the results more closely resemble "gender blindness" in those responsible for the tests. This shows the difficulty when addressing value issues such as gender in educational contexts. The first facet of gender awareness targets preconceptions at the individual level. In other words, Ståhl and Hussénius's analysis makes test designers visible to us as individuals, and it is these individuals' different notions of gender that are operationalized in the test questions. We have different understandings of gender within us at the same time on different levels, and, in addition, some of these ideas can be unconscious. As historian Yvonne Hirdman (2001) describes it, it is the complete tragedy of the constant performance of gender (in the separation of the genders and the raising of the male as superior to the female) that inevitably leads to the contempt for what is considered the "female". Contempt becomes a very essential notion for the continuation of the subordination of women and the socialization of both women and men in this ordering. Women themselves can thus carry within them, consciously or unconsciously and in various degrees, a self-loathing that must be handled and strongly resisted for this self-loathing not to be directed outward toward, for example, students working in school activities (Andersson 2011). Therefore, this is the most difficult and painful facet of gender awareness, but it is unavoidable. Test designers, both women and men, may use facet 1 as a tool to make conscious their possible prejudice. They need to look inward, at themselves, in order to take the next steps to combat the ways gender stereotypes play out, in this case in the construction of test questions in chemistry.

\section{Facet 2: gender awareness in relation to chemistry (which becomes problematized and reviewed)}

Gender awareness and more specific knowledge about gender and feminist theories can be used to study chemistry and its discourses in order to highlight the inherent power aspects, exclusions and so on. Ultimately this could contribute to changing teaching towards more inclusive education. I would like to take a moment to look at the title of Stăhl and Hussénius's article, "Chemistry inside an epistemological community box," where I as an 
interested reader ask myself the question, what kind of epistemological box is this and what kind of chemistry is in this box? Ståhl and Hussénius describe how chemistry in the various discourses slides back and forth, more or less "stable in the contours". In the Disciplinary Discourse Group, there is no doubt about what chemistry is and what knowledge in chemistry is valued. Key factual knowledge and conceptual definitions are in focus here, and in the answer alternatives there is limited room for discussion but, rather, a clear right or wrong. The Disciplinary Discourse Group is dominated by a reductionist approach to knowledge in which the relational, the contextual is downplayed, and I interpret that it is this approach to knowledge that the authors see as within the "epistemological community box," which I henceforth will call the hegemonic chemistry discourse.

As Lindahl (2003) showed in her study of secondary school pupils a repeated result from higher education that women in science and technology education to a greater extent than men ask for teaching that includes dialogue, discussions, overviews and contexts (Salminen-Karlsson 2003). Boys and men refer more to external motivation and instrumentality, whereas internal motivation and content interest are more prominent in girls and women (Wernersson 2006), leading to the conclusion that boys benefit from the hegemonic discourse chemistry. This does not mean that this hegemonic discourse in itself is entrenched in masculinity. Andreas Ottemo's (2015) ethnographic thesis is about the chemistry and information technology training in Sweden, where he, among other things, followed students studying in a chemical engineering program. He argues that the chemistry or other subjects themselves should not be seen as gendered but, rather, that students can take different subject positions, which may be more or less possible depending on their genders. He writes, "[that I] found no support for reductionism, objectivity or subjectlessness itself can be understood as an expression of masculinity. Instead I understand these aspects of teaching as things that implicitly privilege the already impassioned subject" (p. 268). With Hirdman's understanding of gender hierarchy, the notions of suitability, aptitude and other human characteristics are associated with gender on a symbolic level, in our thought structures, which have an impact both structurally in society and individually (Hirdman 2001). Natural sciences and, therefore, chemistry have historically fallen within the realm of men and the potentials and skills that are thus linked to these areas are associated with masculinity. Hirdman believes that the gender hierarchy is driven by keeping the sexes apart, with the man as the norm. Although chemistry in itself is not gendered, those ideas that are most valued in the subject, the hegemony, can hence generate masculine connotations.

In the Transgressive Discourse Group, chemistry's position changes. Ståhl and Hussénius describe the content in chemistry in the Sustainable Development Discourse with the following idea: "Even chemistry has lost its prominent role. It has become almost invisible" (p. 22). They conclude that the test questions related to this discourse are aimed at getting students to use everyday scientific knowledge, not specific chemistry knowledge, to answer the questions, with the result that it does not become clear that chemistry is an aspect of sustainable development. Even so, the test questions dwell upon addressing chemistry's virtues of our society, i.e. its technological developments, but to a lesser degree with describing the responsibilities and the negative effects on society and the environment. The boundaries around chemistry, what can be said to be within the "box's" walls, are in constant motion. Chemistry content within the Sustainable Development Discourse, where chemistry does not have a main role in the test questions, can be compared with the higher education and research in which, for example, environmental chemistry and green chemistry are subject areas (Böschen et al. 2003). Instead of being 
invisible, on the contrary, many chemistry-oriented courses today establish a strong link between chemistry and sustainable development. In Andreas Ottemo's dissertation (2015), students describe the chemical engineering program as steeped in environmental and sustainability issues. But even here, in higher education, there is a lack of critical perspectives on the chemical industry. Statements from students indicate that the courses emphasize a view of the future where technology will be improved to make it more environmentally friendly and reducing use of environmentally hazardous chemicals.

However, chemistry discourses in the Trangressive Discorse Group, could be seen as remnants of chemistry research in connection with the chemical industry that dominated without question until the 1960s. Stefan Böschen, Dieter Lenoir and Martin Scheringer (2003) describe how the scientific establishment attracted great societal confidence until the 1960s when people saw the results of research and industrial production as something that guaranteed for the future social progress and welfare and were either unaware of the risks or were confident that the scientific community could take care of them. This relationship between society, the research community and industry changed during the 1970s when several accidents happened within the chemical industry, and the society/citizens became increasingly suspicious and questioning of this holy alliance between research and the chemical industry, which the newly formed environmental movement also put the spotlight on. The article by Böschen et al. (2003) addresses "Sustainable Chemistry," a way to integrate a sustainable development model with chemistry, and they claim that as late as 2003, this integration was still in its infancy. They argued that the social dimension of sustainable development should also be considered in chemistry, and in this argument, they even ask if chemistry really should belong to the scientific domain. Chemistry's epistemological assumptions must be reconsidered in order to create a mutually productive relationship between scientific work and social needs and values (Böschen et al. 2003).

The development of society with its scientific/technological achievements has given rise to negative environmental impacts that need to be studied using multidisciplinary contributions to be resolved. A concrete example can be seen in the issues surrounding landfills or mining waste dumps. In order to increase knowledge about what happens in these landfills, how to solve the acute problems and how to store chemical waste in the future demands collaboration between inorganic and organic chemists, microbiologists, marine biologists, toxicologists, geologists and others (see, for example, the research team Biogeosphere Dynamics at Örebro University, https:/www.oru.se/english/research/researchteams/rt/?rdb=g195). In these partnerships researchers from various social science domains can advantageously be included in, for example, urban planning, law theory and practice and ethics as well as critical perspectives of gender studies and the sustainable development field. These researchers contribute with different perspectives and thereby create other types of research questions that are relevant for understanding these types of complex problems and their consequences.

In their final words Böschen et al. (2003) assert that schools and universities must be incorporated into the discussion on sustainable chemistry and then incorporate green chemistry into regular chemistry teaching, already implemented in programs around the world:

[w]e need to discuss the extent to which criteria exist that help us make decisions about chemical processes and products in terms of their social desirability. To do this, a conscious approach needs to be developed even before chemists start work. We need to raise awareness as early as possible during students' training at schools and universities. (p. 100) 
Within science education research, issues of sustainability have been present in a number of areas such as socio-scientific issues (see, for example, Zeidler et al. 2005), and science, technology, society and environment (STSE), where an epistemology other than reductionist reigns. Different abilities and skills of the students are in demand and are the focus in these areas (Pedretti and Nazir 2011). Since these areas emphasize democratic values and citizenship, encouraging and developing students' abilities to use science and technology to reflect on moral positions becomes important knowledge content. If this "epistemological box" should be expanded to include more chemistry discourses beyond the hegemonic, it is unfortunate that Ståhl and Hussénius's analysis shows that even for tests with questions covering environmental issues and everyday chemistry, answers that are allowed remain attached to a hegemonic chemistry discourse with a reductionist world view. Students that give reasoning about chemistry's problematic impact on nature, people and the environment-in other words, that demonstrates skills that are valued in socioscientific area-are not awarded full points.

\section{Facet 3: gender awareness in relation to students (to effect change/ improvement in scientific activities)}

All teaching is normative and must be so, and it is based on a number of values, implicit or explicit. Curricula and syllabi articulate standards about what students should learn in a certain area and why this particular knowledge is important and relevant. The teachers' didactic choices (or in this case, the test designers), the selection of subject matter and the way these are presented have implications for students and their learning and interest. In addition to reviewing what happens in the classroom and the different gender performativities made possible there, which include and exclude students, teachers also must be attentive to what subject epistemologies are pervasive in their own teaching. It is easy to assume that one's own interests, one's own way of learning is common to everyone. The beginning of this article includes an excerpt from an upper secondary school teacher who came to understand her own approach to knowledge by hearing how other students view science subjects. Teachers should be able to see from the perspective of others, go outside themselves, and assume that in a classroom the student body always is diverse. This means that chemistry must be presented in various ways, making several chemistry discourses available. The third facet of the gender awareness recognizes the teacher's knowledge of their students and how they are engaged. Nancy Brickhouse (2001) describes how involvement in science content is also connected with identity formation, who we want to be and what content topics we feel connected to. Knud Illeris (2007) points out that the humanities and social subjects in school provide significantly more opportunities for young people to include subject matter with identity formation than science and technology succeed in doing. The hegemonic discourse in chemistry, which in my interpretation is represented by the Discipline Discourse Group, also includes the idea of the ideal chemistry student, a student who the upper secondary school teacher in the introductory excerpt would recognize as such. The ideal chemistry student is a student who can use chemistry concepts, describe chemical reactions, perform calculations, and ask questions that are considered relevant in this discourse, but also perform laboratory work and draw conclusions from experiments. This way of being a chemistry student is also confirmed in Ottemo's study of chemical engineering students (2015). Upon answering interview questions about chemistry courses covering environmental and sustainability "the chemical engineering student"-norm emerges. Students describe the environmental topics as "something different" than the more chemical technology teaching, where the 
environmental aspects are expected to bring other types of reasoning and be discussed more. One student states,

Calculations courses are, like, you're ushered in, you're ushered out, you have this formula to calculate something, done! Here [in the environmental courses], there's more to it, here you can actually discuss and there aren't any correct answers. That's what feels a little difficult for our engineer minds. There are no straight answers, no right or wrong, and maybe that's why we see it as more wishy-washy. (Ottemo 2015, p. 210)

Knowledge and skills that do not fit in the reductionist chemistry discourse feel "difficult" for these students because there is no right or wrong to arrive at through calculations. Not only that, but this is also teaching that is disparaged and described as wishywashy.

Unfortunately, the high-performing students who were interviewed in Lindahl's study chose other programs in upper secondary school rather than the scientific/technical ones. Thus, there need to be different ways to be a chemistry student other than the chemistry student ideal, and several chemistry discourses could possibly open up for this if they are valued equally. As for chemistry test questions, many different aspects of student responses need to be considered equivalent.

\section{Conclusion}

I have used gender awareness' three facets to highlight and discuss some of the results that Ståhl and Hussénius report. The facets function to illuminate educational consequences. Ståhl and Hussénius have shown that the national tests in chemistry in Sweden include several chemistry discourses. These discourses may provide opportunities for more individuals to feel that chemistry is something for them and thus make chemistry their own. The problem is that the different discourses are valued differently. Hopefully, however, this diversity can help to loosen or dislodge the hegemonic discourse. Metaphorically speaking, the epistemological box is not hermetically sealed; one could describe the box walls as permeable. They communicate with the outside world, where new ideas can be admitted but some of the old ones also can seep out.

Acknowledgments Many thanks to Rebecca Ahlfeldt for her valuable help with the translation.

Open Access This article is distributed under the terms of the Creative Commons Attribution 4.0 International License (http://creativecommons.org/licenses/by/4.0/), which permits unrestricted use, distribution, and reproduction in any medium, provided you give appropriate credit to the original author(s) and the source, provide a link to the Creative Commons license, and indicate if changes were made.

\section{References}

Andersson, K. (2011). Lärare för förändring—att synliggöra och utmana föreställningar om naturvetenskap och genus. [Teachers for change-To visualize and challenge conceptions of science and gender]. Studies in Science and Technology Education No 36. Linköping: Linköpings universitet.

Andersson, K., \& Gullberg, A. (2014). What is science in preschool and what do teachers have to know to empower the children? Cultural Studies of Science Education, 9(2), 275-296. doi:10.1007/s11422-0129439-6. 
Böschen, S., Lenoir, D., \& Scheringer, M. (2003). Sustainable chemistry: Starting points and prospects. Naturwissenschaften, 90, 93-102. doi:10.1007/s00114-002-0397-9.

Brickhouse, N. (2001). Embodying science: A feminist perspective on learning. Journal of Research in Science Teaching, 38, 282-295. doi:10.1002/1098-2736(200103)38:3<282::AID-TEA1006>3.0.CO;20 .

Harding, S. (1986). The science question in feminism. Ithaca: Cornell University Press.

Hirdman, Y. (2001). Genus-om det stabila föränderligas former [Gender-On the changeable forms of the stable]. Malmö: Liber.

Illeris, K. (2007). Lärande [Learning]. Lund: Studentlitteratur.

Jakobsson, A. (2013). TEMA: Storskaliga studier. Kunskapsmätningar som paradox och möjlighet. Utbildning och Demokrati, 22(3), 5-12.

Keller, E. F., \& Longino, H. E. (1996). Feminism and science. Oxford: Oxford University Press.

Lindahl, B. (2003). Pupils' responses to school science and technology. A longitudinal study of pathways to upper secondary school. Göteborgs Studies in Educational Sciences 196. Göteborg: Acta Universitatis Gothoburgensis.

Lundqvist, E., \& Lidar, M. (2013). Nationella prov i NO och lärares val av undervisningsinnehåll. Utbildning och Demokrati, 22(3), 85-107.

Ottemo, A. (2015). Gender, body, desire, and technology: Passion and instrumentality in two technical university programs. Gothenburg Studies in Educational Sciences 375. Göteborg: Acta Universitatis Gothoburgensis.

Pedretti, E., \& Nazir, J. (2011). Currents in STSE education: Mapping a complex field, 40 years on. Science Education, 95(4), 601-626. doi:10.1002/sce.20435.

Roberts, D. (2007). Scientific literacy/science literacy. In S. K. Abell \& N. G. Lederman (Eds.), Handbook of research on science education (pp. 729-780). London: Lawrence Erlbaum Associates.

Salminen-Karlsson, M. (2003). Hur skapas den nya teknikens skapare? In B. Berner (Ed.), Vem tillhör tekniken? Kunskap och kön i teknikens värld (pp. 145-173). Lund: Arkiv förlag.

Swedish National Agency for Education. (2011). Chemistry curriculum. http://www.skolverket.se/ laroplaner-amnen-och-kurser/grundskoleutbildning/grundskola/kemi

The global gender gap report 2015 [Elektronisk resurs]. Geneva: World Economic Forum.

Wernersson, I. (2006). Genusperspektiv på pedagogik [Gender perspectives on pedagogy]. Stockholm: Högskoleverket.

Zeidler, D. L., Sadler, T. D., Simmons, M., \& Howe, E. (2005). Beyond STS: A research-based framework for socioscientific issues education. Science Education, 89(3), 357-377. doi:10.1002/sce.20048.

Kristina Andersson holds a Ph.D. in science education. She has also a master's degree in biology and a secondary science teacher degree. Kristina is a senior lecturer at the Department of Education at Uppsala University, Sweden and a guest researcher at the Centre for Gender Research at Uppsala University. 